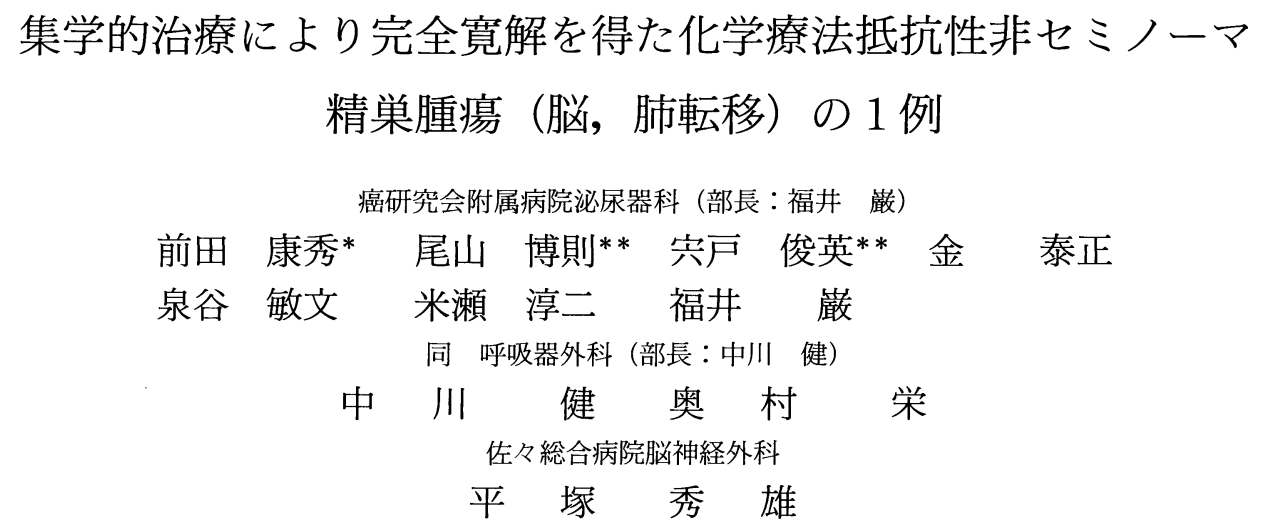

\title{
SUCCESSFUL MANAGEMENT FOR CHEMOREFRACTORY TESTICULAR CANCER WITH BRAIN AND LUNG METASTASES \\ A Case Report
}

\author{
Yasuhide Maeda, Hironori Oyama, Toshihide Shishido, Taisei Kin, \\ Toshibumi Izutani, Jyunji Yonese and Iwao Fukui \\ Department of Urology, Cancer Institute Hospital \\ (Chief: Dr. I. Fukui) \\ Ken Nakagawa and Sakae Okumura \\ Department of Surgery, Cancer Institute Hospital \\ (Chief: Dr. K. Nakagawa) \\ Hideo Hiratsuka \\ Department of Neurosurgery, Sasa Hospital
}

This is a report of successful management for a far advanced, chemorefractory testicular cancer patient. A 29-year-old male was referred to our hospital for the treatment of progressive lung metastases with elevated hCG level, which had recurred after complete remission following 3 courses of BEP chemotherapy and progressed after transient partial regression following 2 courses of intensified EP chemotherapy. In addition, a $3 \mathrm{~cm}$ in diameter, solitary brain metastasis was detected on CT. First, we performed wedge resection of bilateral pulmonary lower lobe for chemorefractory pulmonary metastases. Histological examination revealed viable embryonal carcinoma identical to the primary one. Thereafter, whole brain irradiation in combination with VIP chemotherapy (etoposide $100 \mathrm{mg} / \mathrm{m}^{2}$, cisplatin $20 \mathrm{mg} / \mathrm{m}^{2}$ and ifosfamide $1200 \mathrm{mg} / \mathrm{m}^{2}$ daily for 5 consecutive days) was carried out to treat brain metastasis. By 2 cycles of VIP therapy and irradiation (36 Gy), partial tumor regression and normalization of hCG level were achieved, leading to salvage surgery of the brain metastasis which histologically proved to be necrosis. Following an additional cycle of VIP therapy, the patient has been free of recurrence 24 months after completion of the treatment.

Key words: chemorefractory testicular cancer, salvage surgery, VIP therapy

要旨 : 症例は 29 歳, 男性. BEP 療法後に再発し, 強化 EP 療法に抵抗性の精巣腫瘍肺転移巣の治療目的 で来院した．頭部 CT にて，新たに $3 \mathrm{~cm}$ 大の単発脳転移巣も認めた．我々はまず化学療法抵抗性肺転移 巣を外科的切術した後, 脳肺転移巣に対してVIP 療法と全脳照射を開始した。VIP 療法 2 コースおよび 
放射線 $36 \mathrm{~Gy}$ 照射後, 脳転移巣の縮小ならびに腫瘍マーカーの陰性化を認めたため, 残存腫瘤を摘出し た. 組織所見は壊死組織であった。肺切除組織中に胎児性癌の残存を認めていたため, 術後 VIP 療法を 1 コース追加した。術後 24 力月現在再発の兆しなく生存中である．化学療法抵抗性精巣腫瘍の治療方針 に関して若干の文献的考察を加えた.

キーワード：化学療法抵抗性精巣腫瘍，サルベージ手術，VIP 療法

\section{緒言}

近年, CDDP を中心とする多剤併用化学療法の進歩 に伴い, 精巣腫瘍の治療成績は著しく向上した。しか し,依然として, 進行例の $20 \sim 30 \%$ はR 後に再発した り，初めから化学療法抵抗性を呈する難治例である. これら難治症例のうち複数藏器に遠隔転移を有する場 合，確立された治療方針はなく，その治療は困難を極 めることが多い.

今回我々は, BEP 療法後に再発し, 強化 $\mathrm{EP}$ 療法に 抵抗性の肺転移巣と新たに発見された脳転移巣を有す る再発性精巣腫瘍症例において，まず化学療法抵抗性 の肺転移巣に対して外科的切除を先行し, その後, 脳 転移巣に対して集学的治療を施行し，完全寛解を得る ことが出来た 1 例を経験したので，化学療法抵抗性精 巣腫瘍に対する治療方針について若干の文献的考察を 加え報告する.

\section{症例}

患者：29歳，男性，I.D. 0294186-2.

主訴：精巣腫瘍再発肺転移巣の治療

既往歴：虫垂切除術.

家族歴：特記すべき事なし。

現病歷(図 1)：1992年 9 月某院にて右精巣腫瘍に対 して高位精巣摘除術を受けた. 組織型は胎児性癌で, 腫瘍マーカーは LDH のみ $1,472 \mathrm{IU} / l$ と高值を示し, $\mathrm{AFP}$ と hCG $\beta$ は正常とのことであった. ステージン グの結果, 肺, 肝抢よび後腹膜リンパ節への転移を指 摘された. 精巣腫瘍 stage IIIc の診断のもと BEP 療法

図 1 前医での治療経過

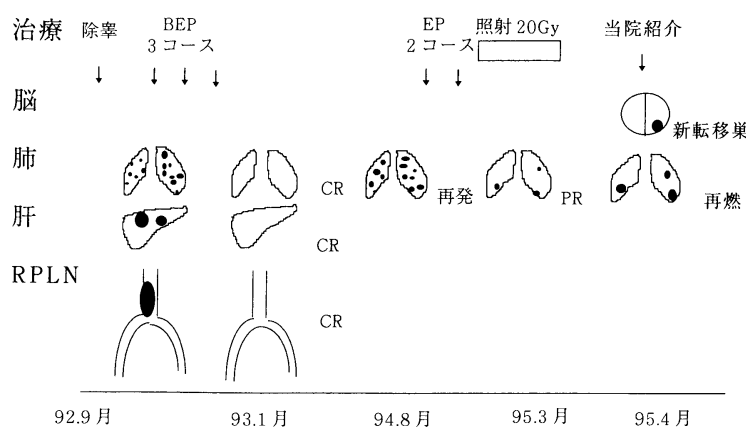

を 3 コース受け，画像上 CR となったため治療は打ち 切られた。その後, 転勤となり他院で経過観察を受け ていたが，1994年 8 月多発性肺転移を指摘された。腫 瘍マーカーは $\mathrm{hCG}$ のみ $6.9 \mathrm{IU} / l$ と軽度高值を示した。 そこで $\mathrm{EP}$ 強化療法 (etoposide $100 \mathrm{mg} / \mathrm{m}^{2}$; 第 1 ～第 5 日， cisplatin $72 \mathrm{mg} / \mathrm{m}^{2}$ ；第 1 日と第 5 日）を 2 コー 又施行され, PR となったが依然, 両肺(右 1 コ, 左 2 コ）に病巣が残存した。右下肺の最大残存病巣に放射 線治療 (20Gy) を受け hCG は正常化したが，その後肺 転移巣増大と共に $\mathrm{hCG}$ 再上昇が認められたため当科 を受診した。

入院時現症：高位精巣摘除術と虫垂切除術による手 術創を認める他は異常を認めず。

入院時検査: $h \mathrm{hCG}$ は $9.2 \mathrm{IU} / l$ と上昇していたが $\mathrm{hCG} \beta, \mathrm{AFP}$ および $\mathrm{LDH}$ は正常であった.また，血 清 FSH は $14 \mathrm{IU} / l$ と軽度上昇を示したが, LH と TSH は正常であった. 腎機能検查にて血清クレアチニン 1.4 $\mathrm{mg} / \mathrm{dl}, \mathrm{Ccr}$ は $70 \mathrm{ml} / \mathrm{min}$ と軽度腎機能障害を認めた。

胸部 CT (図 2A)：右肺 $\mathrm{S}^{10}$ に径 $20 \mathrm{~mm}$, 左肺 $\mathrm{S}^{10}$ に 20 $\mathrm{mm}, \mathrm{S}^{6}$ に $5 \mathrm{~mm}$ の円形陰影を認めた。頭部 MRI (図 3 A)：脳転移を示唆する症状は何ら認めなかったが, 再 発肺転移巣を有するため検索したところ，左後頭落に 直径 $30 \mathrm{~mm}$ 大の単発性腫瘤を認めた。肝，骨，リンパ 節に転移を認めなかった。

入院後経過（図 4 ）：以上より再発性精巣腫瘍（脳, 肺転移）の診断のもと，まず残存肺転移巣に対し楔状 切除術を施行した。病理組織診断にて左肺 $\mathrm{S}^{10}$ の腫瘤 にのみ胎児性癌の残存を認めた（図 $2 \mathrm{~B}$ )。術後 8 日目 より VIP 療法 (etoposide $100 \mathrm{mg} / \mathrm{m}^{2}$, ifosfamide $1,200 \mathrm{mg} / \mathrm{m}^{2}$, cisplatin $20 \mathrm{mg} / \mathrm{m}^{2}$ ； day 1～5）を開始 すると同時に，脳転移巣に対し全脳照射を併用した。 なお入院時軽度腎機能障害を認めたためシスプラスチ ンを $25 \%$ 減量したが，1コース目に grade 4の顆粒球 減少を認めたため，2 コース以降はすべての薬剤を 25\%減量した。照射 (総線量 $36 \mathrm{~Gy}$ ) と VIP 療法 2 コー 又終了時点で, 脳転移巣は $80 \%$ 縮小し（図 3B), hCG も正常化したため, 残存脳転移巣を摘出した. 摘出標 本に viable cell を認めなかったが，肺転移巣に癌の残 


\section{図 2 肺転移巣}

A. 入院時胸部 CT 所見：両肺下共背側に直径 $20 \mathrm{~mm}$ 大の転移巣を認める. B. 肺楔状切除標本（左肺 $\left.\mathrm{S}^{10)}\right)$ ：胎児性癌の残存を認める.
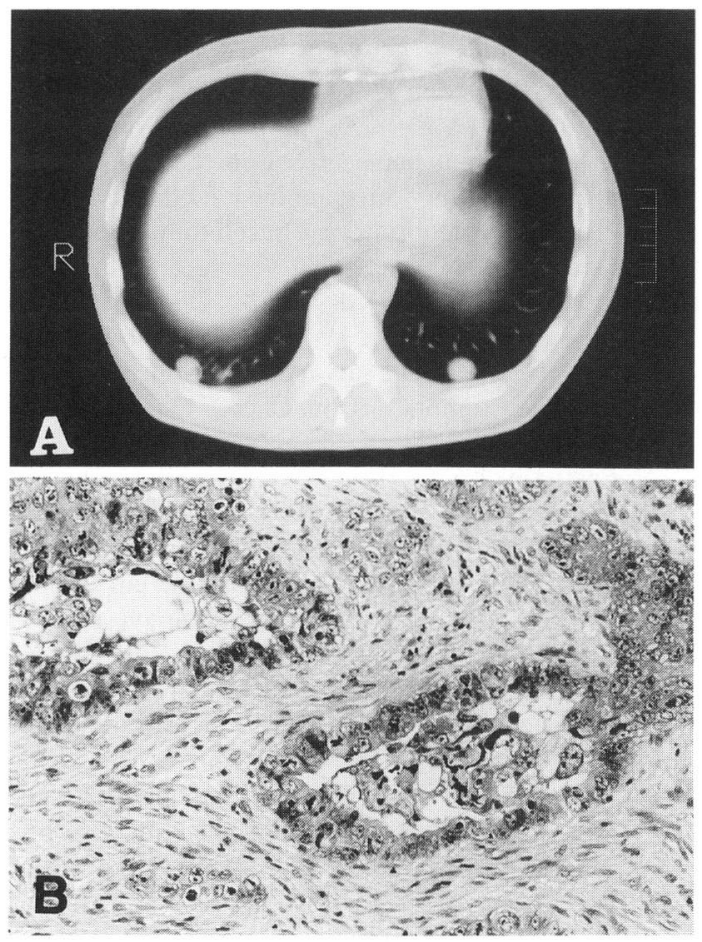

存を認めていたため, VIP 療法を 1 コース追加し退院 させた。脳転移巣手術後24力月経過した1997年 8 月現 在，再発，転移抢よび後遺症を認めず，社会復帰して いる.

\section{考 察}

精巣腫瘍の転移巣が化学療法により縮小せず，腫瘍 マーカーも陰性化しない症例は，他にも活動性の癌細 胞を有する可能性が高く，一般的にサルベージ手術の 適応にはならないとされている1) 4). 自験例は当院入 院時, 肺再発巣と脳転移巣を有していたため, 治療方 針としてはまず全身化学療法を先行し，腫湯縮小と共 に腫瘍マーカーの陰性化をみてから，残存腫瘤を摘出 するという方針が望ましいと考えられる。しかし来院 までの治療経過から，1）肺転移巣は BEP 療法後に再 発し, cisplatin, etoposide を増量した強化 EP 療法に 抵抗性であるため, 類似の cisplatin, etoposide を基調 にした化学療法を施行しても, 効果が得られない可能 性が高いこと，2）大量化学療法を施行するには，すで に度重なる前治療による骨髄予備能と腎機能の低下と
図 3 頭部 MRI(T1造影)

A. 入院時 : 左後頭葉に $3 \mathrm{~cm}$ 大の強く造影される腫 瘍を認める。

B. VIP 療法 2 コース施行後：脳転移巣は $80 \%$ の縮小 をしめした。
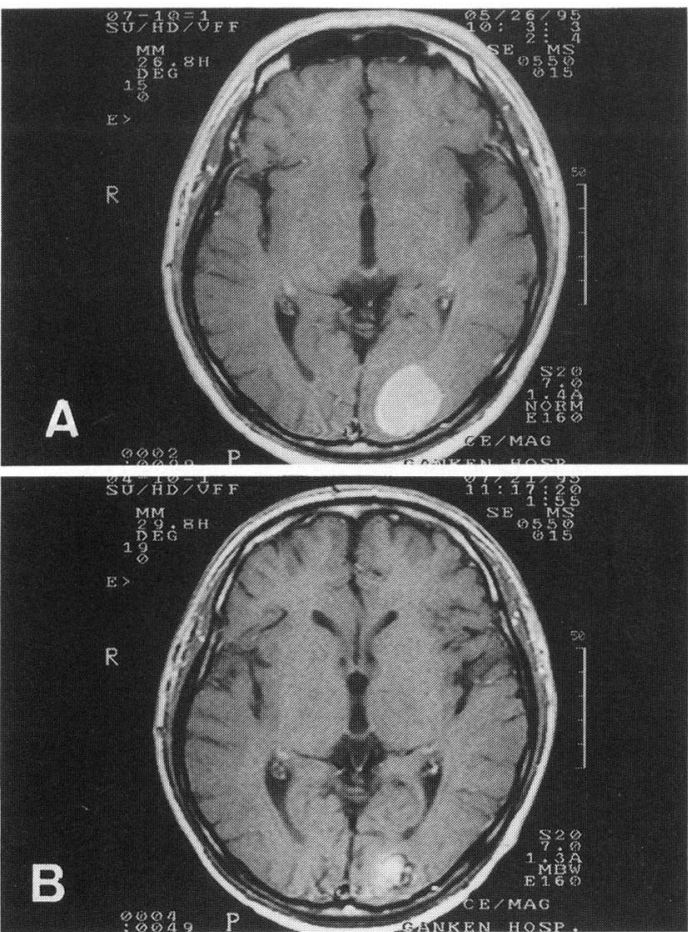

図 4 入院後治療経過

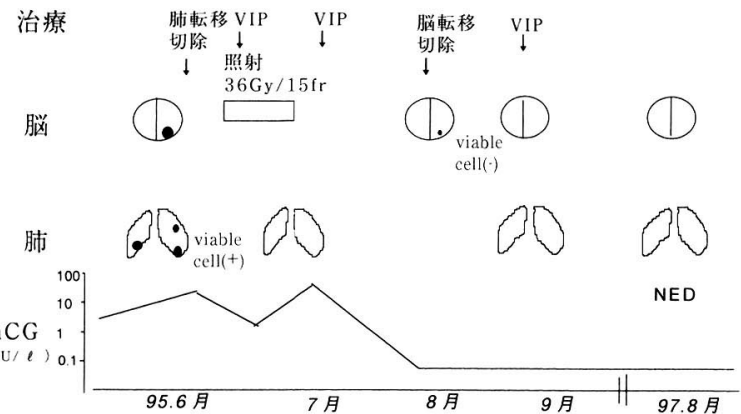

が予測されること,および，3）脳転移巣は, 腫瘍増大 により脸血液関門の破綻が考えられる5 と同時に新病 変でもあるため, 放射線治療の効果 ${ }^{6)}$ のみらず救済 化学療法として報告されているVIP 療法 ${ }^{778)}$ の効果も 期待できると考えた。 そこで腫瘍マーカーは陰性化し ていなかったが，まず化学療法抵抗性の肺転移巣には 外科的切除を先行し, その後脳転移巣に対し, 化学療 
法，放射線治療および外科的切除による集学的治療を 行ったわけである. 救済化学療法として, ifosfamide, cisplatin，vinblastine を併用した VeIP 療法も考えら れるが，有効期間のより長い VIP 療法 ${ }^{8}$ を選択した。

導入化学療法により腫瘍マーカーが陰性化しない症 例に対するサルベージ手術の治療成績としては, Murphy $ら^{2)}$ が48例中10例 (21\%) に, Eastham ら ${ }^{3)}$ が16例 中6例 (37\%) に長期寛解を得たとしており, 化学療法 抵抗例においても救済手術が20～30\%に有効であるこ とを忘れてはならない.しかし，サルベージ手術の適 応としては 2,3 の意見があり, Murphy ら ${ }^{2)} は$ 単一臓 器に限局した完全切除可能な病変で, かつ絶対的に CDDP 抵抗性であることが挙げているが，Woods ら は4), 単一臟器で後腹膜リンパ節にのみ限局した残存 腫瘤で,かつ hCG の上昇を呈した 5 例全例に再発を認 めたことから, AFP のみが上昇している症例に限る, としている.

自験例の如く複数臟器に転移を有する症例に一期的 に手術した場合, Murphy ら ${ }^{2)}$, Eastham ら ${ }^{3)}$ の両者報 告例あわせて19例全例が癌死しており, 複数臟器転移 例での一期的手術は避けるべきであろう. Eastham $ら^{3)}$ は肺と後腹膜リンパ節の 2 カ所に転移巣を認める 場合，まず肺転移巣に対する手術を先行し，その組織 型により後腹膜リンパ節に対する治療を決定するとい う方針を推奨している．すなわち肺転移巣の組織型が 壊死あるいは奇形腫であれば後腹膜リンパ節郭清を行 うが, viable cell を認めれば郭清の前に化学療法を考 慮すべきである，としている，自験例では，転移巣が 肺と脳であるが, 前述した種々の理由から肺転移巣に 対する手術を先行し，その後脳転移巣に対する集学的 治療を行い, 結果的に長期寛解を得ることが出来た。 複数臓器に転移巣をもつ化学療法抵抗性精巣腫瘍に対 するサルベージ手術の適応は慎重に検討せねばならな い重要な課題であるが, 転移巣の状況や治療の順序に ついてよく考えつつ, 症例によっては決してあきらめ ることなく集学的治療に全力を尽くすべきであろう.

なお自験例では, 再発後 LDH, AFP, $\beta$-hCG は常 に正常範囲であり,腫崵マーカーとなったのは hCGの みであった. 当初, 化学療法による造精機能の低下に より FSH が上昇し，これが hCG $\alpha$ 抗体との交叉反応 を示し, みかけ上 hCG 上昇をきたしたのではない か910) と推測した. しかし, その後 FSH が正常化して からも hCG は高值を示し, 経過中唯一の腫場マーカー となった。海外の文献では $\mathrm{hCG}$ と $\beta$-hCG を混合した
報告が多く我々が調べ得た限りでは本症例の様な腫瘍 マーカーに関する報告は見あたらないが，自験例の経 験から, 精巣腫瘍のフォローアップの際, $\beta$-hCG 陰性 例においては hCG を測定することも時に有用である ことが示唆された。

\section{文献}

1) Bajorin, D.F., Herr, H., Motzer, R.J. and Bosl, G.J.: Current perspectives on the role of adjunctive surgery in combined modality treatment for patients with germ cell tumors. Semin. Oncol., 19, 148-158, 1992

2) Murphy, B.R., Breeden, E.S., Donohue, J.P., Messemer, J., Walsh, W., Roth, B.J. and Einhorn, L.H.: Surgical salvage of chemorefractory germ cell tumors. J. Clin. Oncol., 11, 324-329, 1993.

3) Eastham, J.A., Wilson, T.G., Russell, C., Ahlering, T.E. and Skinner, D.G.: Surgical resection in patients with nonseminomatous germ cell tumor who fail to normalize serum tumor markers after chemotherapy. Urology., 43, 74 $-80,1994$.

4) Wood, D.P., Herr, H.W., Motzer, R.J., Reuter, V., Sogani, P.C., Morse, M.J. and Bosl G.J., Surgical resection of solitary metastases after chemotherapy in patients with nonseminomatous germ cell tumors and elevated serum tumor markers. Cancer., 70, 2354-2357, 1992.

5）福井 巌, 東 四郎, 木原和徳, 後藤修一, 安島純 一, 小林信幸, 吉野修治, 児島真一, 高木健太郎, 松原 修: Salvage chemoterapy の奏効した殬 丸腫揚脳転移の 1 例. 日泌尿会誌, 77, 1207-1213, 1986.

6) Logothetis, C.J., Samuels, M.L. and Trindate, A.: The management of brain metastasis in germ cell tumor. Cancer., 49, 12-18, 1984.

7) Motzer, R.J., Bajorin, D.F., Vlamis, V., Weisen, S. and Bosl, G.J.: Ifosfamide-based chemotherapy for patients with resistnt germ cell tumors: The Memorial Sloan-Kettering Cancer Center experience. Semin. Oncol., 19, 8-12, 1992.

8) Loehrer, P.J., Lauer, R., Roth, B.J., Williams, S. D., Kalasinski, L.A. and Einhorn, L.H.: Salvage therapy in recurrent germ cell cancer: ifosfamide and cisplatin plus either vinblastion or etoposide. Ann. Int. Med., 109, 540-546, 1988.

9）大久保雄平, 福井 嚴, 坂野祐司, 吉村耕治, 前田 浩, 米瀬淳二, 山内民男, 河合恒雄, 奥村 栄, 石 川雄一：後腹膜原発絨毛癌の 1 例. 日泌尿会誌, 86, 1784-1788, 1995.

10) Mason, M.D.: Tumor markers. in Testicular Cancer: Investigation and management, 2nd ed., p35-51, Chapmann \& Hall, London, 1996.

（1997年9月10日受付，1998年5月19日受理） 